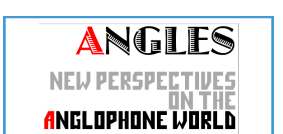

ANELOPHONE WORLI

\section{Angles}

New Perspectives on the Anglophone World

$10 \mid 2020$

Creating the Enemy

\title{
Meeting the Enemy
}

British-German Encounters in the Occupied Rhineland after the First World War

\section{Tom Williams}

\section{Q OpenEdition \\ 1 Journals}

\section{Electronic version}

URL: http://journals.openedition.org/angles/488

DOI: $10.4000 /$ angles.488

ISSN: 2274-2042

\section{Publisher}

Société des Anglicistes de l'Enseignement Supérieur

\section{Electronic reference}

Tom Williams, « Meeting the Enemy », Angles [Online], 10 | 2020, Online since 01 April 2020, connection on 28 July 2020. URL : http://journals.openedition.org/angles/488 ; DOI : https://doi.org/ 10.4000 /angles. 488

This text was automatically generated on 28 July 2020

\section{(c) (i) (2)(2)}

Angles. New Perspectives on the Anglophone World is licensed under a Creative Commons AttributionNonCommercial-ShareAlike 4.0 International License. 


\section{Meeting the Enemy}

British-German Encounters in the Occupied Rhineland after the First World War

\section{Tom Williams}

1 Negative stereotypes of the German enemy were so pervasive in Britain during the First World War that, when crossing into German territory at the end of the conflict, the writer and social reformer Violet Markham remarked that it was "almost with a shock that you realise that German civilians are not equipped with hoofs and horns or other attributes of a Satanic character" (Markham 1921: 15). Visions of a brutal, arrogant, warmongering "Hun", disseminated since 1914 in British propaganda as a means of justifying wartime mobilization and sacrifice, proved difficult to sustain once British soldiers and civilians met individual Germans face-to-face in the occupied Rhineland. However effective they may be as a propaganda tool for galvanising public opinion in wartime, enemy images inevitably require a process of psychological abstraction, relying on a set of beliefs and assumptions that often bear little relation to sociohistorical realities or individual experiences (Rieber \& Kelly 1991; Oppenheimer 2006). It should be no surprise, therefore, that individual encounters on the Rhine proved far more complex and often more troubling than the black-and-white propaganda images of wartime. As Violet Markham reflected, it was "easy to hate the abstraction called Germany, but for individual Germans one feels either like, dislike, or indifference, the same as for other people" (Markham 1921: 88).

2 Markham was far from alone in making such an observation. As many other British writers, journalists, soldiers and administrators in the Rhineland observed, day-to-day encounters with an often disconcertingly friendly civilian population tended to break down the negative wartime stereotypes (Williamson 1991: 5). Proximity bred sympathy, and phrases such as "yesterday's enemy" or "our former enemy" quickly became commonplace in British accounts, embodying a mood of reconciliation in the Occupied Rhineland that was at odds with the Germanophobia of the British public and press (Wittek 2005: 393). As one British observer in Germany put it in August 1919 when trying to explain attitudes in the Rhineland to readers at home: "we don't have your perspective. Living as close to him as we do, we lose sight of that indefinite, loathly, 
blood-dripping horror called 'the Boche"' (The Bystander, 20 Aug. 1919). However, it was not easy for British occupiers and observers in Germany to abandon this enemy image entirely, not least because negative characterizations of Prussian militarism and German brutality had played an important role in justifying not only British involvement in the war but also the punitive conditions of the peace. In the context of this post-war occupation certain specific features of the wartime enemy image were therefore sustained and reinforced. To some British observers, for example, the friendliness of the Rhineland population only served to confirm the servile disposition of the Germans towards any authority, or the existence of a division in Germany between a liberal, peace-loving and civilized south and west and the "real" enemy: an autocratic, militarist and expansionist Prussia. Meanwhile, the attitude and behaviour of the British occupiers was regularly measured not only against how the Germans had treated the populations of occupied regions of France and Belgium during the war, but also against how the stereotypical "Hun" would have behaved in the case of a German victory. Despite the initial shock of encountering friendly German civilians, aspects of the enemy image thus persisted throughout the occupation years, albeit in less overt ways than in wartime propaganda.

3 This article examines how the encounter between the British occupiers and the Rhineland population both modified and, in more subtle ways, perpetuated wartime images of the German enemy. In order to do so, it first situates the image of the German enemy in British propaganda during the First World War within the wider context of shifting, and often positive, British views of Germany since the late $19^{\text {th }}$ century. Although it is impossible to offer a detailed analysis of pre-war and wartime views of Germany within the scope of this article, it is nevertheless helpful to sketch out this broader context in order to underline both the complexity of British views of Germany before 1918 and the (contested) continued relevance of negative stereotypes after the defeat of the German Empire in November 1918. Secondly, by examining a wide range of first-hand accounts written by British occupiers, journalists and travellers in the occupied Rhineland it reveals how the encounter with the occupied population altered British attitudes towards Germany while still allowing certain negative stereotypes, particularly relating to Prussia, to be perpetuated. Finally, drawing on the same eyewitness accounts, it explores how the self-image of the British occupiers in the Rhineland was constructed not only in opposition to the enemy image of the German occupier, perpetuating pre-existing suppositions and negative stereotypes, but also in opposition to the actions of the French on the Rhine which, conversely, gave rise to a more positive, sympathetic view of the Germans. Although several of the eye-witness accounts examined in this article were written by journalists, it does not seek to assess the impact on British public opinion of images of Germany promulgated by the mass media, a subject which has been dealt with in meticulous detail elsewhere (Schramm 2007; Wittek 2005). Instead, by concentrating on first-hand accounts written by British occupiers and observers who spent a significant amount of time in the Rhineland, it seeks to assess how, on an individual level, face-to-face encounters with German civilians reshaped and often prompted sustained reflections on the wartime image of the enemy. 


\section{The Enemy Image during the First World War. Origins, Functions, Tensions}

4 When war broke out in August 1914, the image of a brutal, barbaric and militaristic German (or Prussian) enemy would already have been familiar to much of the British public. Evidence of such negative stereotypes can be found in British discussions of Germany since the 1860s, when military victories over Denmark in 1864, Austria in 1866 and France in 1870 paved the way towards the foundation of the German Empire under Prussian leadership. To cite just one example, Lord Arthur Russell characterized Prussia in 1872 as the antithesis of "liberal and democratic ideas", listing among Prussian traits "military despotism, the rule of the sword, contempt for sentimental talk, [and] indifference to human suffering" (Wittek 2005: 79). As the new German Empire grew into an industrial and technological powerhouse, and began to challenge Britain's maritime dominance after the first German Naval Laws of 1898, concerns regarding British deficiencies tended to be reflected in those characteristics attributed to Germany: technocracy, ruthless efficiency, militarism and illiberalism (Rau 2009: 2-4; Scully 2012: 316-7; Rüger 2007). As tensions between the two countries were stoked further by the actions of Kaiser Wilhelm II - most famously by the Kruger Telegram of 1896, in which he congratulated the Boers for repelling the Jameson Raid, and the Daily Telegraph Affair of 1908, in which he was quoted as referring to the British as "mad as March hares" - negative images in the British press, presenting the German Empire as power-hungry, unpredictable and a threat to international stability, became increasingly bound up with the portrayal of the Emperor himself (Reinermann 2008). By the time of the Entente Cordiale in 1904, Germany had replaced France as Britain's most likely potential conqueror in popular "invasion literature", including Erskine Childers' The Riddle of the Sands (1903), William Le Queux's The Invasion of 1910 (1906) and Saki's When William Came (1913) (Rau 2009: 65-88). On the eve of the First World War, popular Germanophobia in Britain even extended to hostility towards the sale of German sausages in Britain (Waddington 2013).

Despite much uncertainty as to how Germany's rising power would affect Britain's position in the world, however, it would be far too simplistic to claim, as one recent study of pre-war Anglo-German relations has done, that by the late 1890s "an entire generation of Britons and Germans [...] had come to age having imbibed a consistent, and consistently negative, view of each other" (Hawes 2014: 404). For much of the $19^{\text {th }}$ century, the German Empire had been widely admired in Britain for achievements in fields as varied as music and literature, philosophy and education, science and technology, and social welfare reform (Davis 2007; Geppert \& Gerwarth 2008; Major 2008). The Rhine remained popular with British travellers, while German universities continued to attract ambitious British students (Schulz-Forberg 2002: 101-2). There were just as many positive depictions of Germany in pre-war English literature as there were Germanophobic invasion stories (Argyle 2002; Rau 2009). Even on the eve of the First World War, British views of Germany were complex and multifaceted, characterized not only by antagonism but also by a great deal of admiration, as well as ambivalence (Scully 2012: 316). The British and the Germans had never previously gone to war against each other and could look back on a long tradition of political cooperation, as well as strong dynastic, cultural, religious and economic ties (Kennedy 1980: xi). A study of students in Oxford and Heidelberg has found that, rather than 
German and British elites drifting apart in the pre-war years, "life was slowly but steadily moving in the right direction" (Weber 2008: 223). Thus, even if negative images of Germany were present in British culture before 1914, the wide range of British attitudes towards Germany and the Germans cannot be summed up simply in terms of an "enemy image".

Once war broke out, however, pre-existing negative images of Prussian/German autocracy, militarism and brutality were readily taken up by British propaganda (Wittek 2005: 82). After the German violation of Belgian neutrality, Britain was presented as having reluctantly taken up arms to defend high moral and legal principles against "Prussian bullying" and a German state bent on world domination (Welch 2015). As Adrian Gregory has observed, "every step on the way to the demonization of Germany was prompted by real events, albeit events interpreted in a highly partisan framework" (Gregory 2008: 40). Reports of German atrocities against Belgian and French civilians during the first weeks of the war were presented in British propaganda as proof of the "monstrous" character of the German nation, providing a framework for interpreting the war as a struggle between civilization and barbarism (Horne \& Kramer 2001: 296). The apocalyptic tone of British atrocity propaganda was typified by Barry Pain's poem "In the Trail of the Hun":

Villages burned down to dust;

Torture, murder, bestial lust,

Filth too foul for printers' ink,

Crimes from which the apes would shrink (cited in Robb 2015: 124)

7 Moreover, as Pain's reference to "bestial lust" implies, many reports of German "beastliness" concentrated on the enemy's supposed sexual aggression and outrages against female civilians (Frost 2002: 20-2; Gullace 1997). After the destruction of Louvain university library and the bombardment of Rheims Cathedral, The Times presented Kaiser Wilhelm II as "the modern Attila", his troops as "ruthless barbarians", their crimes as "without a parallel even in the Dark Ages" and the war as the concern of "every nation on the side of humanity and progress, all peoples who do not wish to see Christian civilization submerged beneath a flood of barbarism." (The Times, 29 August 1914 and 21 September 1914). In 1915, the first large-scale use of poison gas at the Second Battle of Ypres, the sinking of the Lusitania, aerial attacks on the British mainland by German Zeppelins and the publication of the Bryce Report on Alleged German Outrages all further reinforced this image of German barbarity and disregard for civilized norms (Schramm 2007: 384; Grayzel 2012: 55). These powerful images of German "beastliness" and atrocities committed against women and children by a "monstrous Hun" soon overshadowed Britain's original war aims as the focus of wartime propaganda, the more abstract causes of defending Belgian neutrality and honouring treaty commitments giving way to the emotional appeal of redressing German atrocities and standing up to the "Prussian bully" (Buitenhuis 1987: 9-10; Pick 1993: 155). When combined with the notion that Britain and her allies were the defenders of civilization and justice, the enemy image thus became inseparable from the rationale for the war itself.

8 This does not mean, however, that pre-existing, positive views of Germany, particularly as a cultural or scientific role-model, were abandoned entirely or that there was immediately universal approval in Britain for viewing all Germans as the enemy. Some British commentators continued to insist on need to distinguish between "two Germanies": a militarist, expansionist Prussia on the one hand and a peaceful, civilized 
southern and western Germany on the other (Pulzer, 1996: 235-50). The Chancellor of the Exchequer, David Lloyd George, declared in September 1914, for example, that "we are not fighting the German people. The German people are under the heel of this military caste" (Kuropka 1984: 120). However, in response to reports of German war enthusiasm in August 1914 and to German attempts to defend the actions of the German army in Belgium and France, such a distinction was downplayed. It was argued instead that the whole of German society had been thoroughly "Prussianized" since 1871 (Muir 1914: 113; Robbins 1999: 27). When, in October 1914, an appeal "to the civilized world" was published by 93 German scientists, writers and academics, defending German actions in Belgium and insisting that Germany would continue to fight the war "as a civilized nation", British propaganda simply found a new target: the blood-thirsty German professor (see, for example, The Globe, 22 Oct. 1914). By 1916 The Times was warning against the "dangerous fallacies" inherent in the notion of "two Germanies", arguing that even "such great strongholds of the other, non-military, Germany as Hamburg, Cologne, and Frankfurt have been conspicuous in the German Press for the vehemence of their war spirit" (The Times, 27 Jan. 1916). As the war dragged on, the notion of "two Germanies" thus had ever-decreasing value for wartime propaganda, despite not disappearing from British debates entirely.

Following the abdication of the Kaiser and the signing of the Armistice in November 1918, the "two Germanies" idea suddenly became relevant once more, several British observers expressing their optimism that the defeat of German imperialism and Prussian militarism might allow the "other" peaceful Germany to re-emerge. The former British officer George Young, for example, expressed his hope that, after the downfall of "Kaiserism", the German Revolution would prove "strong enough to exorcise the evil genius of Prussianism and of Junkerism" (Young 1920: 10). Similarly, the war correspondent Philip Gibbs, who was among the first to enter Germany with the British occupying forces in November 1918, felt hopeful that the "death of militarism" would be "cleansing to the soul of Germany" and that "she will emerge from all those years of evil cleaner and brighter and kinder" (Gibbs 1921b: 202). However, despite military surrender and the proclamation of the Republic, the enemy image of the war years - that of a pointy-helmeted "Prussian Ogre" or "Beastly Hun" capable of heinous acts of vandalism and cruelty against innocent women and children - did not disappear when the armistice was signed. In Britain an atmosphere of recrimination prevailed: calls were made in the press to "make Germany pay" and "hang the Kaiser", and a Ministry of Information film with the catchphrase "once a Hun, always a Hun" insisted that there should be no trading with Germany after the war (Sanders \& Taylor 1982: 162). It was in such an atmosphere of war-weariness, recrimination, hope and uncertainty that British troops entered German territory as occupiers in November 1918.

\section{"Unintelligibly friendly": Encounters with German Civilians, 1918-1930}

10 As a condition of the Armistice, the left bank of the Rhine was occupied by the armies of Britain, France, Belgium and the United States. The British were allocated a zone of occupation centred on Cologne, where they remained, in gradually diminishing numbers, until 1926, when they withdrew to a new, smaller zone around the city of 
Wiesbaden. As a result, even though British stereotypes of the enemy were closely bound up with images of German (or Prussian) militarism, the first Germans encountered by the British in the Rhineland were almost exclusively civilians, all military forces having been required to withdraw to fifty kilometres beyond the Rhine. In the demilitarized Rhineland the most obvious visual components of the wartime enemy image - spiked helmets and military uniforms - had all but disappeared from the streets. As one press report on life in post-war Cologne put it: "The Soldier has gone; the Civilian has come - to stay" (The Graphic, 14 June 1919). According to another British visitor to the Rhineland, "with their uniforms off, their absurd martial arrogance put aside", the Germans were revealed as "flesh and blood human beings" (Nottingham Journal, 1 March 1921). Although such observations, printed in British newspapers with relatively low circulation figures, may not have counteracted the general mood of recrimination and Germanophobia in the British media at the end of the war (Schramm 2007: 494-6), they nevertheless reveal the effect that face-to-face encounters in the post-war Rhineland had on individual attitudes towards the wartime enemy image. After four years of wartime propaganda, encounters with civilians often proved, at the very least, surprising and disconcerting to the British when they crossed the frontier into German territory.

In an account of the end of the war entitled Back to Life (1921), Philip Gibbs recalled his astonishment to be told by a young German, in the first village across the frontier, that "the war is over, and we can be friends again." Already surprised by such an attitude from the defeated enemy, Gibbs was even more amazed to find that the men of the British cavalry patrol "did not seem to be nourishing thoughts of hatred and vengeance" and quickly began chatting to German civilians in a friendly manner. "We had been in the German village ten minutes", recalled Gibbs: "There was no sign of hatred here, on one side or the other. Already something had happened which in England, if they knew, would seem monstrous and incredible. A spell had been broken" (Gibbs 1921: 146). According to Gibbs, face-to-face encounters quickly broke the spell of wartime propaganda or, as he recalled one British officer reflecting, "hatred of a nation breaks down in the presence of its individuals [...] in spite of five years' education in savagery." (Gibbs 1921: 158) As a result of such friendly encounters, Gibbs writes, the gap between the attitude of British soldiers and civilians in Germany and public opinion at home widened: "if old men from St. James's Street clubs in London, and young women in the suburbs clamouring for the Kaiser's head, could be transported straight to Cologne without previous warning of the things they would see", he declared, "they would go raving mad" (Gibbs 1921: 155). Gibbs reflected on the same themes in The Hope of Europe, also published in 1921, concluding that the natural friendliness of German-British encounters involved "a recognition that these people, anyhow, were human souls, not individually guilty of atrocities, not 'Huns' in their manners and ideas, not particularly responsible for the war, and jolly glad, like our people, that it was over at last" (Gibbs 1921b: 169). However, when he returned to the same theme once again in his 1923 novel The Middle of the Road, his British protagonist finds this realisation disconcerting, struggling to make sense of the fact that "within a few days after the occupation of Cologne, British soldiers had clinked beer-mugs with the fellows who had once lain behind machine-guns, mowing them down". Faced with the friendliness of the civilian population, this former soldier finds it "impossible to keep up the old hate against them" yet at the same time "reproached himself for having forgotten 'the Enemy' so completely that he could shake hands with a German 
(so violating an ancient vow) without any sense of repugnance". Thus, in both his memoirs and this fictionalized account, Gibbs recalled the psychological adjustment the British had to make when re-considering their wartime image of the enemy.

The bewildering friendliness of the local population, often met with incredulity, resentment and suspicion on the part of the British occupiers, is a recurrent theme in British accounts of the occupation. The military historian and MP Charles Oman, who visited Cologne in April 1919, wrote of his "overwhelming impression [...] that the Germans were astoundingly, and indeed unintelligibly friendly" (Oman 1933: 248). This absence of any signs of resentment was, according to Oman, "puzzling, and rather unpleasant" to the British, not least because they "all came to Germany with a very strong prejudice against the Germans" as a result of German "outrages" against civilians during the war. "These were hard to forget", continued Oman, "and it was surprising to find that our involuntary hosts obviously expected us to be quite without prejudice against them" (Oman 1933: 251). Such puzzlement at German attitudes was compounded by the feeling that British civilians would not have responded so positively to the arrival of conquering German troops. B.T. Reynolds, a British officer billeted in the home of a German widow in Benrath, was surprised by the friendliness of the Germans he encountered: "I couldn't help feeling, the whole time, that I should have felt very different if the roles had been reversed and a German officer had been billeted in my house" (Reynolds 1933: 33-4). Similarly, the English painter William Rothenstein, attached to the Canadian Army as a war artist, was struck by how many German civilians came to admire his canvas as he painted a British gun on the banks of the Rhine: "had the Germans won and placed a gun on the Thames-side in London, and a German painter been painting it, no Englishmen would have said, "How beautiful"' (Rothenstein 1932: 357). Canadian soldiers serving in the British Occupied Area felt equally confused, finding that any desire for revenge against Germany "died away into a sort of exasperated bewilderment" when they came into contact with "the mild and docile Hun" (Macpherson 1920: 259). In a letter home, the Canadian soldier John McKendrick Hughes recorded his surprise that a large crowd of German onlookers had gathered to watch the arrival of a Guard's Division in Cologne in January 1919, apparently without any feelings of resentment, and wondered: "Would we do the same if the Prussian Guards were marching through Edmonton or London? I cannot understand it" (Hughes 2005: 217). As the British journalist Ferdinand Tuohy put it "the eternal mystery of the Boche attitude never ceased to be a fruitful tea-table topic" (Tuohy 1931: 221).

13 Such difficulty in understanding German attitudes stemmed in part from the gap between the expectations of the British and the reality they encountered. The AngloIrish writer Katharine Tynan, who arrived in Cologne in 1923 with "an expectation of enmity" (Tynan 1925: 59), was instead confronted with "that friendliness which is the bewilderment of every English-speaking new-comer" (4). On the whole, she found the lack of enmity between the British and Rhinelanders an agreeable surprise, but she "never tired of wondering about the mind of the Rhinelander" (179) and assumed that, below the surface, old hatreds still persisted (59). Tynan was also able, occasionally, to identify individual Germans who conformed to her expectations of the enemy image, recalling that in the hotel where she stayed "there were two of the waiters who looked everything that propaganda had told us of the German. [...] One could always see these two 'coming over' through the smoke of the barrage" (6). The persistence of aspects of the enemy image can also be seen in the account of the occupation years by Violet 
Markham, who lived in Cologne for over a year from March 1919 while her husband was Chief Demobilization Officer for the Army of the Rhine. Markham found the experience of the occupation beneficial insofar as it brought "the enemies of yesterday in touch, and so help[ed] to break down a certain amount of prejudice." (Markham 1921: 208) She felt that "the wholesale indictment of a nation" was absurd because "there are good Germans and bad Germans, Germans animated by a quite detestable spirit, others who are conscientious and high-minded." (218) Despite such remarks, Markham's account nevertheless regularly condemns Prussia and the "evil spirit let loose by the Prussian theory of Life" (250-1), holds the Junkers responsible for the war $(106,115,215,219)$ and reserves especially critical remarks for German professors, who she claimed, were "notorious for their bloodthirstiness" (206-7). In Markham's account, the image of the Prussian enemy is never far away: she informs readers, for example, that an old housekeeper whom she disliked "had the hall-mark of the Prussian on her" (25). Looking back on the experience of occupation in her 1953 autobiography, Markham admitted that a memory of reports of German wartime atrocities had left her "puzzled by the discrepancies between our personal impressions and a darker, more sinister side of the German character". She felt, however, that the negative image of the enemy "only applied to a minority, certainly not the pleasant, friendly people among whom we were living" (Markham 1953: 159). Thus, the friendly attitude of German civilians may have destabilized British images of the enemy, but it did not dispel them completely.

One of Markham's most perceptive remarks relates to the way in which the British in the Rhineland tended to interpret German behaviour through the prism of their own prejudices. She noted that "some of the English in Cologne ha[d] arrived at fixed judgments about Germany before setting foot in the country. If they find the inhabitants civil they at once call them servile, if they show spirit they denounce them as insolent" (Markham 1921: 209). A reviewer of Markham's book recorded his own, similar experiences of life in the Rhineland: "On first thoughts I imagined the people of Cologne and the district to be disgustingly servile. Afterwards I suspected hypocrisy. Thirdly, and finally, I came to the opinion that their nature, brutal or kindly, arises from amazing docility towards authority, good or bad" (Nottingham Journal, 1 March 1921). Similarly, Ferdinand Tuohy considered German friendliness evidence of "that undoubted streak of servility which lies enfolded in the German character" (Tuohy 1931: 221), while an article in The Scotsman interpreted it as proof that the Germans lacked any sense of shame and were "as arrogant and conceited as ever" (The Scotsman, 18 April 1919). Major Seabury Ashmead-Bartlett of the Royal Field Artillery put forward an equally negative interpretation of German friendliness, suggesting that "having been beaten they are anxious to placate their conquerors, as is the way with bullies all the world over" (Ashmead-Bartlett 1921: 185). In other words, even German friendliness could confirm, in the eyes of the British, the negative stereotypes of the enemy promulgated during the war. The fact that large crowds turned up to watch British military ceremonies was attributed by some authors to a German fondness "for pomp and goose-stepping" (Tuohy 1931: 218; see also Tynan 1925: 179). Only very rarely did British interpretations of German friendliness recognize the reality: that polite cooperation was also motivated by fear and by the hope that good relations with the British might bring lighter sanctions (Van Emden 1996: 43).

In his attempt to understand German attitudes, Ashmead-Bartlett also proposed an alternative explanation for the friendliness of the Rhineland population, namely that 
"the Rheinländer are not real Germans, feel little, if any, attachment to the Prussian system and are decent people at heart" (Ashmead-Bartlett 1921: 185). Reviving the long-standing suppositions about "two Germanies", this regional explanation for the lack of enmity encountered in the Rhineland was regularly put forward by the British (and even more so by the French) during the occupation. B.T. Reynolds, for example, noted that the "whole outlook and mentality" of the Prussian was "very different from that of the Rhinelander" (Reynolds 1933: 96), while Robert Coulson, who spent four years in the occupied Rhineland, noted that the Prussian, known for his "frosty formality, his mentality, which was autocratic or subservient according to his position, had nothing in common with the temperamental freedom-loving gaiety of the Rhinelander" ("Apex" 1931: 126). Similarly, the former army officer and war correspondent for the Daily Telegraph Charles à Court Repington reported from the Rhineland that "there is nothing of the Prussian here. No stiff formalism, no bluster and swagger, but the easy ways of would-be happy dwellers in their fruitful valleys" (Repington 1922: 220). This supposed contrast between Rhinelanders and Prussians was discussed at length by former British intelligence officer G.E.R. Gedye who published a series of articles in The Bystander under the pen-name Eric Gordon while employed as a secretary to the Inter-Allied Rhineland High Commission (see Wittek 2005: 110-6). Though written in a light-hearted manner, his articles gave a damning account of the Prussian enemy. In March 1922, for instance, Gedye warned that the British, while living alongside "an easy-going friendly race" among picturesque vineyards and ruined castles in the Rhineland, were likely to forget that "all Germans are not Rhinelanders" and that the "real, square-headed Prussians east of the Elbe" were "narrow intolerance personified" (The Bystander, 8 March 1922). The enemy image of wartime propaganda, Gedye argued, did not apply to the Rhinelander since "the typical German, as we imagine him, is really a typical Prussian" (The Bystander, 21 Jan. 1920).

It was not only the British, of course, who made such claims, which were also put forward by the French in their attempt to promote separatist movements in the Rhineland (Nadler 1987), as well as by the mayor of Cologne, Konrad Adenauer, in the hope that the Rhineland city might be spared the full brunt of British anti-Prussianism (Williamson 1991: 19). The notion of Prussian (as opposed to German) responsibility for the war was certainly a useful political argument in the Rhineland: in March 1919, The Times reported on complaints from the population of Cologne that they were being made to pay for the sins of "a few Prussians" (The Times, 12 March 1919). Whether such claims were made by the British, by the French, or by the Rhinelanders themselves, however, they did not dismantle the enemy image entirely, but simply shifted it geographically eastwards, beyond the frontiers of the British occupied area. Thus, while many British commentators could not help but acknowledge that their experience in the Rhineland rarely corresponded to their expectations of the German enemy, their explanations for this discrepancy frequently fell back on pre-existing, negative stereotypes regarding Prussia and Prussian militarism. This tendency can also be observed in unpublished military memoirs of the occupation. One British officer, when surprised by the co-operative attitude of the Rhineland population, concluded that "maybe the Rhinelanders are different to those further East and the Prussians", rather than abandoning his wartime image of the enemy completely (IWM 6827: 27-28). Another officer, struck by the beauty of German classical music during his stay in Cologne, did not let this experience dispel his view of the "real nature" of the Prussian militarist enemy: "how different, I thought, from the real nature of the German 
warlords" (IWM 1467: 66). Some British visitors, meanwhile, simply refused to recognize any such division between "two Germanies", emphasizing instead the continuing loyalty of the Rhinelanders to the "Prussian spirit" (Butler, 1921: 300), or to the "Junker element of East Prussia" and the "pernicious doctrines of the Professor class" (Bacon 1921: 225-6).

\section{"An Army of Gentlemen": The British Occupiers in a German Mirror}

17 Several British accounts attributed the good relations between the occupiers and the occupied not to any specific traits of the German character, but to what Sir Douglas Haig referred to, when praising the conduct of British troops in Cologne in his final despatch, as the "inborn courtesy and good temper of the British soldier" (Haig 1919: 319). Violet Markham, for example, claimed that good relations and the lack of German animosity towards the British occupiers was evidence of "the half-unconscious genius of our race for government" (Storer 2010: 69). There was, in other words, a clear tendency among British observers in the Rhineland to attribute the benevolent, orderly conduct of the occupiers to inherent "British" national characteristics. Implicitly or explicitly, this self-image was constructed in opposition to the image of the German enemy. Thus, even though the wartime enemy image was a less overt presence during the Rhineland occupation, it was nevertheless implicit in the British tendency to measure their own conduct against the behaviour, real or imagined, of the German enemy.

The symbolic importance attached to the supposedly irreproachable conduct of the British as occupiers could be interpreted as an attempt to compensate for the fact that, during the war itself, Allied claims to moral superiority had hardly been clear cut. Although the British public had been outraged by the German uses of chlorine gas, aerial bombardment against civilians and unrestricted submarine warfare, Britain had quickly followed suit in the case of the first two, while the third was partly a response to the equally morally problematic British naval blockade that sought to starve German civilians into submission. Condemnation of Britain's supposed ruthlessness in maintaining the anti-German "hunger-blockade" had played a prominent part in German wartime propaganda, alongside criticisms of Britain's colonial expansionism and violence against subject peoples including the Boers and the Irish (Stibbe 2001). The conduct of British troops in the Rhineland therefore had a particular symbolic importance when it came to restoring Britain's standing in Germany. Given that British wartime propaganda had emphasised German "frightfulness" towards the populations of conquered neighbouring territories, and Britain had never occupied German territory during the war, the Rhineland occupation was an opportunity to demonstrate the supposed moral superiority of the Allies over their wartime enemies. At a time when, from Ireland to India, British violence against civilians was being condemned as "Prussianism", it was also an opportunity for the British to defend their national reputation in the face of accusations of hypocrisy and double-standards (Pick 1993: 150; Lawrence 2003: 572; Sayer 1991).

Even before the occupation began, the contrast between German and Allied behaviour had been anticipated in the British press. The Times, for example, proclaimed in 1914 that, unlike the Germans in France, "the Allies have clean hands, and when in turn they 
march through Germany they will keep them clean" (The Times, 21 Sept. 1914). After British troops entered Germany, accounts of their conduct regularly made comparisons with a stereotyped image of German militarism. Noting the "remarkable tact" displayed by British occupiers in 1919, The Times claimed that there was "nothing overbearing" in British behaviour and contrasted the iron discipline of Prussian militarism with "British" traditions of good sportsmanship when describing British troops playing football "on a parade ground which but a short while ago was devoted to the cult of the goose step" (The Times, 6 May 1919). Another article, recalling an alleged contrast in the conduct of British and German soldiers during the Napoleonic wars a century previously, called upon the British army to maintain its "great tradition" of "admirable discipline" and "humane and soldierly conduct", which stood in marked contrast to "the systematic and savage brutality of the German troops". British occupation, the same article concluded, would teach the Germans a lesson "in the treatment of civilians by the occupying soldiers of a just but generous democracy" (The Times, 9 Dec. 1918). Like several other British commentators, this journalist even suggested that the German population had grown to prefer the rule of the British enemy to the iron rule of Prussian militarism before 1918 (Jeffery 2005: 456).

While comparisons were frequently made with the nature and conduct of German militarism in the past, it was even more common in British discussion of the Rhineland to contrast British behaviour with the imagined conduct of the enemy, had the Central Powers been victorious. In order to understand the fundamental differences between the British and the Germans, Ferdinand Tuohy argued, "one had but to conjure in the mind's eye (and Britons on the Rhine seldom tired of it) Prussian conquerors swaggering through London" (Tuohy 1931: 221). Violet Markham, similarly, felt that "if the war had come to a different end, we should have felt the full weight of the Prussian jackboot. The Boche as a conqueror can be intolerable - swollen-headed, swaggering, brutal" (Markham 1921: 67). An English teacher who had lived in Cologne before the war, Alexander Meff, arrived at the same conclusion, praising the British for behaving with "no swagger, no arrogance, no Vae Victis insolence. If one can imagine the unthinkable and suppose a German army holding London, what insufferable arrogance we should have had to endure!" (The Graphic, 14 June 1919). Even the strained relations between the wives of British officers and their German hosts were compared favourably to the equivalent situation in the case of a German victory: "Conjure conquering Hausfraus as dictatresses in English halls and kitchens (no, it was never as bad as that might have been!") (Tuohy 1931: 225). Similarly, when commenting on the British treatment of German prisoners of war, G.E.R. Gedye wrote that "we can hardly imagine Germans treating our prisoners in the same spirit, any more than we can imagine them occupying the East Coast in the easy, if rather contemptuous manner which is the keynote here". Like so many other British commentators, Gedye attributed this contrast to supposed differences in national character: "we are not Germans, and it is not in the British nature to vent on a number of luckless individuals whom fate has left defenceless, the indignation felt against the nation as a whole". Ironically, in the light of such sweeping statements, Gedye also claimed in the same article that an ability to make a distinction between "the enemy" as an abstract concept and "individual members of that enemy" was in itself a "truly British characteristic" (The Bystander, 20 August 1919).

21 Almost inevitably, the actual behaviour of British troops did not always live up to the high standards of this national self-image. In fact, the British representative on the 
Armistice Commission, General Haking, had already warned Field Marshal Haig in December 1918 that "we cannot expect that our troops will necessarily behave better in Germany than the Germans did in Belgium and France" (Williamson, 1991: 17). Yet when British troops behaved poorly during the occupation, they were criticized for not living up to expectations. Neville Stephen Lytton, a British officer and grandson of the writer and politician Edward Bulwer Lytton, wrote that the impression made by the British on the inhabitants of Cologne in the first few days of occupation was "shockingly bad", listing among its faults open fraternization, public drunkenness and a "general impression of vacillation that created the worst possible effect on the German mind". Lytton saw this as all the more regrettable for the fact that style and decorum were so crucial to the British self-image: "The average German", claimed Lytton, "knows that he is more industrious and a more thorough organizer than we are, but he does believe or did believe that we had more style and were gentlemen; I am afraid that on this occasion we must have shattered his last ideal about us" (Lytton, 1921: 217-8). National stereotypes of the Germans, including in this case some positive ones, formed a constant point of reference in discussions of British conduct.

Despite occasional criticisms, most accounts of the British army on the Rhine agreed that the excellent discipline and irreproachable conduct of the British had made a more positive impression on the German population than any of the other Allied armies (The Times, 19 Dec. 1919) and that the British zone around Cologne was as a haven of peace and goodwill in comparison to the neighbouring French zone (The Times, 30 Nov. 1923). The French were often presented as treating their defeated enemy more harshly than the British, motivated by age-old hatreds that far surpassed those of even the most Germanophobe British occupier. Violet Markham argued, for example, that "it cannot be expected that France with the memories of 1870 and 1914 burnt deep into her very marrow [...] can approach the tasks of occupation in the same spirit as the more detached Britons who have less to forget" (Markham 1921: 28). Katharine Tynan, similarly, noted that the French were "good haters and they had reasons to hate" (Tynan 1925: 121). Other British visitors attributed French attitudes to certain national characteristics as well as to past experiences, Frank Hedges Butler, for example, declaring that although "Frenchmen of course have cause for their bitterness [...] the British temperament is different to that of our Gallic friends" (Butler 1920: 300). However strong the rivalry and antagonism between Britain and Germany had been before the First World War, there was certainly nothing in the British case that could compare with the construction of the myth of "hereditary enemies", that had characterized French-German relations since 1870 (Jeismann 1991; Nolan 2004).

As well as marking the high point of tension between the French and the Germans, the Franco-Belgian occupation of the Ruhr from 1923 to 1925 also exposed the differences of opinion between the British and their wartime allies. While the British government adopted an ambiguous policy of neutrality, the British press (with the significant exception of Lord Northcliffe's Daily Mail) tended to take a sympathetic view of the Germans at this time, presenting the population of the Ruhr as victims of French aggression (Wittek 2005: 272-277). In this context, Robert Coulson claimed, many British occupiers and observers on the Rhine not only tended to feel sympathetic towards the Germans but even came to believe that the French "had become their enemies" ("Apex" 1931: 18). Henry Nevinson, sent to the Ruhr to report for the Manchester Guardian, was a harsh critic of France's policy arguing that "the resolve of France to trample her enemy in the dust" would only increase German hatred and sow 
the seeds of a future war, while claiming that "nearly all English people [...] naturally sympathise[d] with those who are down and are still being kicked though they are down" (Manchester Guardian, 3 Dec. 1923). In spite of what he saw as Britain's culpable neutrality, Nevinson thus attributed Britain's unwillingness to join with the French as evidence of "British" benevolence and fair-mindedness, and also noted with some satisfaction, in his autobiographical account of the period that the British army in Cologne "upheld its fine reputation for justice, good-nature, and decent behaviour" (Nevinson 1928: 292). The initial French invasion of the Ruhr led many Germans to look upon the British "as protectors, if not as friends" (Tuohy 1931: 230) and, as Katharine Tynan noted, "the British Occupation must have had its best chance of being popular in the fact that it was side by side with the French" (Tynan 1925: 121). However, British inaction soon became the target of German resentment, reviving well-worn clichés of Anglo-Saxon hypocrisy, "perfidious Albion" or Britain as a "false friend" ("Apex" 1931: 60; The Times, 29 Dec. 1924). Such criticisms, and British sensitivity towards them, perhaps only go to illustrate how differently from the French the British were expected to behave towards their defeated enemies.

When the last British troops began to withdraw from the Rhineland in the final months of 1929, accounts in the British press emphasized the positive impression made by the British occupiers on the Germans. In such reports, the stereotypical British self-image and an implicit comparison with the French were a constant presence. Ferdinand Tuohy, for instance, praised the British for being "so tactful and unassertive in handling Jerry" during what he described as "a very gentlemanly occupation" (The Graphic, 24 Aug. 1929). Reporting from Wiesbaden in December 1929, The Times claimed that "the British troops [left] with the townspeople a high reputation for justice, fair-dealing and politeness" (The Times, 13 Dec. 1929), while the Manchester Guardian drew attention to the tributes paid by the Berlin press to the British for leaving "not as enemies" and in a "gentlemanly fashion" (Manchester Guardian, 18 Sept. 1929). The Germans, British readers were informed, had come to appreciate the fact that "the meaning of British military justice was fair play to all", while the British "army of gentlemen" was able to return home "leaving nothing but peace and good will behind it" (The Times, 23 Dec. 1929). Such statements reflected the official British interpretation of a decade of occupation. When Tom Shaw, the Secretary of State for War in Ramsay MacDonald's Labour government, wrote to congratulate General William Thwaites, Commander in Chief of the British Army of the Rhine, for the exemplary way his troops had conducted themselves, he insisted that they had successfully "maintained the British reputation for chivalry, courtesy and fair play", a statement widely reprinted in the British press including in The Times and The Manchester Guardian on 14 September 1929. This constant emphasis on "British" characteristics, as well as the implication that the German population had been taught some kind of lesson through their encounter with the British, once again reinforced the notion that the attitude of the enemy, in the case of a German victory, would have been strikingly different.

In general, there can be little doubt that personal encounters between British occupiers and German civilians during the Rhineland occupation had a positive effect in breaking down wartime enemy images. Looking back on the Rhineland occupation in the early 1930s, B.T. Reynolds reflected that "the British soldier is a lovable soul and I really think that the presence of British troops on German soil went a long way towards reducing the ill effects of war-time propaganda on both sides" (Reynolds 1933: 51). 
Certainly, face-to-face encounters with individual Germans exposed the British occupiers to a far more nuanced picture of German society than wartime propaganda had permitted. Nevertheless, images of the German enemy promulgated during the war - relating both to Prussian militarism in particular and the German national character more broadly - were able to endure in the context of the occupation, albeit in more subtle ways. Indeed, British commentators even found it necessary to fall back on these stereotypes when trying to explain the friendly attitude of the local population towards their British occupiers. Moreover, the British self-image in the Rhineland was frequently constructed in opposition to a real or imagined German counterpart. Thus, while face-to-face encounters during the years of post-war occupation on the Rhine helped make British attitudes towards Germany at least as nuanced and multifaceted as they had been before 1914, long-standing stereotypes of the German enemy were not entirely dispelled, even in the minds of many of those who experienced the occupation first hand. Given how closely the image of Prussian militarism, the "Beastly Hun" and the bloodthirsty German professor became bound up with British war aims and justifications for sacrifice, it was difficult to abandon such images entirely without calling into question both the meaning of war and the harshness of the post-war treaties, of which the very presence of British troops on the Rhine was a direct consequence. When war broke out again in 1939, remarkably similar national stereotypes, similarly bound up with images of Prussian militarism, would be mobilized once again in British propaganda, and even went on to shape Britain's policy towards Germany during its second experience of post-war occupation after 1945 (Cooper 1998; Kettenacker 1984).

\section{BIBLIOGRAPHY}

Argyle, Gisela. Germany as Model and Monster: Allusions in English Fiction, 1830s-1930s. Montreal \& Kingston: McGill-Queen's UP, 2002.

Ashmead-Bartlett, Seabury H. From the Somme to the Rhine. London: John Lane, 1921.

Bacon, Alban F.L. The Wanderings of a Temporary Warrior: A Territorial Officer's Narrative of Service (and Sport) in Three Continents. London: Witherby, 1922.

Buitenhuis, Peter. The Great War of Words: British, American, and Canadian Propaganda and Fiction, 1914-1933. Vancouver: U. of British Colombia P., 1987.

Butler, Frank Hedges. Fifty Years of Travel by Land, Water and Air. London, T.F. Unwin, 1921.

Cooper, Robert. “The Myth of Prussia”. In Cyril Buffet and Beatrice Heuser (eds). Haunted by History: Myths in International Relations. Oxford: Berghahn Books, 1998.

Davis, John R. The Victorians and Germany. Bern: Peter Lang, 2007.

Frost, Laura. Sex Drives: Fantasies of Fascism in Literary Modernism. Ithaca: Cornell UP, 2002.

Gedye, G.E.R. The Revolver Republic: France's Bid for the Rhine. London: Arrowsmith, 1930. 
Geppert, Dominik and Robert Gerwarth, eds. Wilhelmine Germany and Edwardian Britain: Essays on Cultural Affinity. Oxford and London: German Historical Institute and Oxford UP, 2008.

Gibbs, Philip. Back to Life. London: Heinemann, 1921.

Gibbs, Philip. The Hope of Europe. London: Heinemann, 1921[b].

Gibbs, Philip. The Middle of the Road. London: Hutchinson, 1923.

Grayzel, Susan R. At Home and under Fire: Air Raids and Culture in Britain from the Great War to the Blitz. Cambridge: Cambridge UP, 2012.

Gregory, Adrian. The Last Great War: British Society and the First World War. Cambridge: Cambridge UP, 2008.

Gullace, Nicoletta F. "Sexual Violence and Family Honor: British Propaganda and International Law during the First World War". The American Historical Review 102.3 (June 1997): 714-747. DOI: 10.1086/ahr/102.3.714

Haig, Douglas. Sir Douglas Haig's Despatches (December 1915-April 1919). Ed. by J.H. Boraston. London and Toronto: J.M. Dent \& Sons Ltd, 1919.

Hawes, James. Englanders and Huns: The Culture-Clash which Led to the First World War. London: Simon \& Schuster, 2014.

Horne, John and Alan Kramer. German Atrocities 1914: A History of Denial. New Haven: Yale UP, 2001. Hughes, John McKendrick. The Unwanted: Great War Letters from the Field. Edmonton: U. of Alberta P., 2005.

Jeffery, Keith. “'Hut ab', 'Promenade with Kamerade for Schokolade' and the Flying Dutchman: British Soldiers in the Rhineland, 1918-1929. Diplomacy and Statecraft 16.3 (2005): 455-473. DOI: $10.1080 / 09592290500207735$

Jeismann, Michael. Das Vaterland der Feinde: Studien zum nationalen Feindbegriff und Selbstverständnis in Deutschland und Frankreich, 1792-1918. Stuttgart: Klett-Cotta, 1992.

Kennedy, Paul. The Rise of the Anglo-German Antagonism, 1860-1914. London: Allen and Unwin, 1980. Kettenacker, Lothar. "Preußen-Deutschland als britisches Feindbild im Zweiten Weltkrieg”. In Bernd-Jürgen Wendt (ed.). Das britische Deutschlandbild im Wandel des 19. und 20. Jahrhunderts. Bochum: Brockmeyer, 1984. 145-170.

Kuropka, Joachim. “'Militarismus' und das 'Andere Deutschland'. Zur Entstehung eines Musters britischer Deutschlandinterpretation”. In Bernd-Jürgen Wendt (ed.). Das britische Deutschlandbild im Wandel des 19. und 20. Jahrhunderts. Bochum: Brockmeyer, 1984. 103-124.

Lytton, Neville Stephen. The Press and the General Staff. London: W. Collins Sons, 1921.

Macpherson, J.S.B. "From Mons to the Rhine". In Various Authors, Canada in the Great World War. Volume V. Toronto: United Publishers of Canada, 1920. 230-262.

Major, Patrick. "Britain and Germany: A Love-Hate Relationship?”. German-History 26.4 (2008). DOI: 10.1093/gerhis/ghn045

Markham, Violet R. Watching on the Rhine. New York: George H. Doran, 1921. First published in Britain as A Woman's Watch on the Rhine. London, Hodder and Stoughton, 1920.

Markham, Violet R. Return Passage: The Autobiography of Violet Markham, C.H. London, New York and Toronto: Oxford UP, 1953. 
Nadler, Henry. The Rhenish Separatist Movements during the Early Weimar Republic. New York: Garland, 1987.

Nolan, Michael E. Mythologizing the Enemy in France and Germany, 1898-1914. New York and Oxford: Berghahn, 2004.

Oman, Charles. Things I Have Seen. London: Methuen, 1933.

Oppenheimer, Louis. "The Development of Enemy Images: A Theoretical Contribution”. Peace and Conflict 12.3 (2006): 269-292. DOI: 10.1207/s15327949pac1203_4

Pick, Daniel. War Machine: The Rationalisation of Slaughter in the Modern Age. New Haven: Yale UP, 1993.

Pulzer, Peter. "Vorbild, Rivale und Unmensch: Das sich wandelnde Deutschlandbild in England, 1815-1945.” In. Hans Süssmuth (ed.). Deutschlandbilder in Dänemark und England, Frankreich und den Niederlanden, Baden-Baden: Nomos, 1996. 235-50.

Rau, Petra. English Modernism, National Identity and the Germans, 1890-1950. Farnham: Ashgate, 2009. Repington, Charles à Court. After the War. London: Constable and Company, 1922.

Reynolds, B.T. Prelude to Hitler: A Personal Record of Ten Postwar Years in Germany. London: Jonathan Cape, 1933.

Rieber, Robert W. and Robert J. Kelley, "Substance and Shadow: Images of the Enemy". In. Robert W. Rieber (ed.). The Psychology of War and Peace: The Image of the Enemy. New York and London: Plenum Press, 1991.

Rieger, Bernhard. Technology and the Culture of Modernity in Britain and Germany, 1890-1945.

Cambridge: Cambridge UP, 2005

Robb, George, British Culture and the First World War. 2nd Ed. London and New York: Palgrave, 2015.

Robbins, Keith. Present and Past: British Images of Germany in the First Half of the Twentieth Century and their Historical Legacy. Göttingen: Wallstein Verlag, 1999.

Rothenstein, William. Men and Memories, Recollections of William Rothenstein, vol. 2. 1900-1922.

London: Faber \& Faber, 1932.

Rüger, Jan. The Great Naval Game: Britain and Germany in the Age of Empire. Cambridge: Cambridge UP, 2007.

Sanders, M.L. and Philip M. Taylor. British Propaganda during the First World War. London and Basingstoke: Macmillan Press, 1982.

Sayer, Derek. "British Reaction to the Amritsar Massacre 1919-1920”. Past and Present 131 (May 1991): 130-164. DOI: $10.1093 /$ past/131.1.130

Schramm, Martin. Das Deutschlandbild in der britischen Presse 1912-1919. Berlin: Akademie Verlag, 2007.

Scully, Richard. British Images of Germany: Admiration, Antagonism and Ambivalence, 1860-1914. Basingstoke: Palgrave Macmillan, 2012.

Schulz-Forberg, Hagen. “The Sorcerer's Apprentice: English Travellers and the Rhine in the Long $19^{\text {th }}$ Century". Journeys: The International Journal of Travel and Travel Writing 3.2 (2002): 86-110.

Stibbe, Matthew. German Anglophobia and the Great War, 1914-1918. Cambridge: Cambridge UP, 2001. Storer, Colin. Britain and the Weimar Republic: The History of a Cultural Relationship. London: I.B. Tauris, 2010. 
Tuohy, Ferdinand. Occupied, 1918-1930: A Postscript to the Western Front. London: Thornton Butterworth, 1931.

Tynan, Katharine. Life in the Occupied Area. London: Hutchinson, 1925.

Van Emden, Richard. "Die Briten am Rhein, 1918-1926: Panorama einer vergessenen Besatzung." Geschichte in Köln: Zeitschrift für Stadt- und Regionalgeschichte 40.1 (1996): 39-60. DOI: 10.7788/gik. 1996.40.1.39

Waddington, Keir. “We Don't Want Any German Sausages Here!” Food, Fear, and the German Nation in Victorian and Edwardian Britain. Journal of British Studies 52 (2013): 1017-1042. DOI: $10.1017 / \mathrm{jbr} .2013 .178$

Weber, Thomas. Our Friend "The Enemy": Elite Education in Britain and Germany Before World War I. Stanford: Stanford UP, 2008.

Welch, David. "Images of the Hun. The Portrayal of the German Enemy in British Propaganda in World War One'. In David Welch (ed.). Propaganda, Power and Persuasion: From World War I to Wikileaks. London: I.B. Tauris, 2015. 37-61.

Williamson, David G. The British in Interwar Germany: The Reluctant Occupiers. Oxford: Berg

Publishers, 1991.

Wittek, Thomas. Auf ewig Feind? Das Deutschlandbild in den britischen Massenmedien nach dem Ersten Weltkrieg. Munich: Oldenbourg, 2005.

Young, George. The New Germany. London: Constable and Company, 1920.

Unpublished sources: Imperial War Museum (IWM)

IWM Documents 1467: Private Papers of Lieutenant P. Creek.

IWM Documents 6827: Private papers of Major William James Nicholson.

\section{Newspaper sources}

The Bystander

The Globe

The Graphic

The Manchester Guardian

The Nottingham Journal

The Scotsman

The Times

\section{ABSTRACTS}

When British soldiers and civilians entered the Allied-occupied Rhineland after the First World War, they were often surprised to discover that the individual Germans they encountered had little in common with the image of the enemy promulgated by British propaganda during the war. While face-to-face encounters with an often disconcertingly friendly civilian population inevitably forced the British to re-evaluate their wartime visions of the enemy, certain negative stereotypes of the German enemy nevertheless persisted in the context of the occupation. 
Several British commentators even found it necessary to fall back on these stereotypes when trying to explain the friendly attitude of the local population. To some, German friendliness only served to demonstrate the servile disposition of the Germans towards any form of authority; to others, it confirmed the existence of a supposed division in Germany between a liberal, peaceloving and civilized south and west and the "real" enemy, an autocratic, militarist and expansionist Prussia. Moreover, the British self-image in the Rhineland was frequently constructed in opposition to a real or imagined German enemy. The attitude and behaviour of the occupiers was regularly presented as characteristically "British" and measured not only against how the Germans had treated the populations of occupied regions of France and Belgium during the war, but also against how the stereotypical "Hun" would have behaved in the case of a German victory.

Lorsque soldats et civils britanniques sont entrés en Rhénanie occupée après la Première Guerre mondiale, ils ont souvent été surpris de découvrir que les Allemands rencontrés avaient peu en commun avec l'image de l'ennemi véhiculée par la propagande britannique pendant la guerre. Si les rencontres individuelles avec la population civile, souvent surprenante par son comportement amical, ont poussé les Britanniques à réévaluer leurs visions de l'ennemi, certains stéréotypes négatifs de l'ennemi allemand ont néanmoins persisté pendant l'occupation. Ils permirent parfois, aux yeux de certains témoins britanniques d'expliquer l'attitude amicale de la population locale. Pour certains, la gentillesse de la population Rhénane ne servait qu'à démontrer la disposition servile des Allemands à l'égard de toute forme d'autorité ; pour d'autres, elle confirmait l'existence d'une prétendue division en Allemagne entre un sud-ouest libéral, pacifique et civilisé, et le "véritable » ennemi : la Prusse autocratique, militariste et expansionniste. De plus, l'image que l'occupant britannique en Rhénanie avait de lui-même fut fréquemment construite en opposition avec un ennemi allemand réel ou imaginé. L'attitude et le comportement des occupants furent régulièrement présentés comme «typiquement britanniques » et opposés non seulement au comportement des Allemands envers les civils français et belges pendant la guerre, mais aussi à la manière dont la figure stéréotypée du «Boche » («Hun ») se serait comportée dans l'hypothèse d'une victoire allemande.

\section{INDEX}

Mots-clés: ennemi, occupation, Rhénanie, stéréotypes, relations anglo-allemandes, Première Guerre mondiale

Keywords: enemy, occupation, Rhineland, stereotypes, Anglo-German relations, World War I

\section{AUTHOR}

\section{TOM WILLIAMS}

Tom Williams is maître de conférences in British Studies at the University of Angers and a member of the Centre Interdisciplinaire de Recherche sur les Patrimoines en Lettres et Langues (CIRPALL). He has a doctorate in Modern History from the University of Oxford. His research focuses on nationalisms and regionalisms in the British Isles and German-speaking Europe, and on histories of travel in the era of the two world wars. Contact: tom.williams[at]univ-angers.fr 